\author{
ALICJA BUDNIK \\ Zakład Ekologii Ewolucyjnej Człowieka, Instytut Antropologii \\ Wydział Biologii, Uniwersytet im. Adama Mickiewicza w Poznaniu
}

\title{
MOŻLIWOŚCI ODTWARZANIA STRUKTURY GENETYCZNEJ POPULACJI NA PODSTAWIE ŹRÓDEL HISTORYCZNYCH
}

Trudno przeceniać wagę badań nad genetyczną strukturą populacji ludzkich. Mają one wymiar zarówno praktyczny, jak teoretyczny. Można dzięki nim empirycznie weryfikować wyprowadzone wcześniej teoretycznie modelowe równania $\mathrm{z}$ zakresu genetyki populacyjnej. Można ponadto rekonstruować i wyjaśniać różnorakie aspekty z zakresu historii i ekologii lokalnych grup ludzkich. Badania te służą zatem odtwarzaniu mikroewolucji człowieka (Budnik 2000).

Współcześnie, w dobie dynamicznego rozwoju metod i technik z zakresu biologii molekularnej, do rekonstrukcji struktury genetycznej grup ludzkich zaprzęga się coraz częściej badania DNA. Badania te, jakkolwiek ciekawe i ważne z poznawczego punktu widzenia, są jednak skomplikowane i kosztowne. Strukturę genetyczną populacji próbuje się jednak odczytywać także w bardziej tradycyjny sposób, ze źródeł historycznych, demograficznych, archiwalnych. Przyjrzyjmy się, w jaki sposób można powiązać oba rodzaje danych, jak ,przetłumaczyć” wzajemnie na siebie dane genetyczne i demograficzne.

Różnice genetyczne w zakresie danego locus między lineażami w obrębie tej samej populacji można wyrazić za pomocą wariancji częstości danego allelu ustandaryzowanej na kombinację średniej częstości tego allelu we wszystkich lineażach i jego alternatywnego wariantu. Wariancja jest tu matematyczną miarą zmienności genetycznej. W terminach genetyki populacyjnej określamy ją jako tzw. wariancję Wahlunda (Cavalli-Sforza i Bodmer 1971; Henneberg 1978). Ta standaryzowana wariancja genetyczna stanowi równocześnie współczynnik wsobności (inbredu) w populacji: 


$$
f=\frac{\sigma^{2}}{\bar{p} \bar{q}}=\frac{1}{1+4 N m}
$$

gdzie: $f$ - współczynnik wsobności, $\bar{p}, \bar{q}$ - średnie częstości alternatywnych alleli danego locus, jeśli w locus znajdują się tylko dwa allele, wtedy $\bar{q}=1-\bar{p}$, $\sigma^{2}$ - wariancja genetyczna częstości danego allelu, $N$ - efektywna wielkość populacji, $m$ - współczynnik migracji.

Jak wynika z podanych wyżej formuł, wariancja genetyczna zależna jest od rozmiarów populacji, a dokładniej od tzw. efektywnej wielkości populacji $N$ (w uproszczeniu możemy tu przyjąć, że jest to liczba osób zdolnych do kojarzeń małżeńskich i reprodukcji) oraz od tego, ile alleli będzie napływało do badanej populacji za sprawą migracji (od współczynnika migracji $\mathrm{m}$ ) (Cavalli-Sforza i Bodmer 1971). Już tu zatem pojawia się przełożenie danych genetycznych na kulturowe, demograficzne. Współczynnik wsobności oznacza prawdopodobieństwo, że losowo wybrany z populacji osobnik posiada w danym locus dwa allele identyczne ze względu na pochodzenie od tego samego przodka. Współczynnik wsobności mierzy zatem stopień homozygotyczności populacji. Pod pewnymi względami przypomina on współczynnik tzw. wewnątrzgrupowego spokrewnienia. Współczynnik spokrewnienia wewnątrzgrupowego to prawdopodobieństwo, że u dwóch losowo kojarzących się w populacji osób w danym locus występuje taki sam allel i że ta identyczność wynika z pochodzenia od tego samego przodka. Gdy kojarzenie małżeństw w grupie ludzkiej odbywa się losowo, nie ma w niej migracji oraz nie zachodzą mutacje, oba współczynniki są tożsame (Cavalli-Sforza i Bodmer 1971). Zauważmy, że współczynnik spokrewnienia wewnątrzgrupowego dotyczy pokolenia rodziców, współczynnik wsobności - pokolenia potomstwa.

Największe prawdopodobieństwo szybkiej i zauważalnej przebudowy puli genowej zaznacza się w małych, izolowanych populacjach. Zwrócił na to uwagę już w czterdziestych latach ubiegłego wieku jeden z twórców genetyki populacyjnej, Sewall Wright. Podane wcześniej równanie na współczynnik inbredu $f$ stanowi uproszczoną postać wzoru dla tzw. wyspowego modelu międzygrupowej wymiany genów, jaki stworzył ten autor (Cavalli-Sforza i Bodmer 1971; Jorde 1980). Model ten dotyczy bardzo nielicznych przypadków populacji, które położone są w dużym oddaleniu od innych (jak wyspy) i wymieniają z nimi $\mathrm{w}$ bardzo niewielkim stopniu, $\mathrm{z}$ małym natężeniem migracji, osobniki a wraz z nimi geny. W rzeczywistości ta wymiana partnerów (i genów) odbywa się na ogół inaczej, bo różne jest rozmieszczenie populacji w przestrzeni i różne są systemy kojarzeń małżeńskich. W sytuacjach najczęściej spotykanych u człowieka trudno znaleźć wyraźne i bezwzględne bariery izolacyjne. Ze względu na niepełność lub brak takich barier trudno jest też wydzielić zbiory osób posiadających odrębne pule genów. $Z$ drugiej strony, nie sposób też traktować 
populacje ludzkie jako grupy nieograniczonego kojarzenia się, całkowicie panmiktyczne. Pamiętajmy, że nawet przy braku barier izolacyjnych, prawdopodobieństwo zawarcia małżeństwa zależne jest od odległości geograficznej. Mówimy wówczas o ,izolacji przez odległość” (isolation by distance) (CavalliSforza i Bodmer 1971; Henneberg 1976; 1979; Jorde 1980).

Zaproponowano wiele modeli oceny stopnia tej izolacji. Wymiana genów w przestrzeni zamieszkałej przez ludzi może odbywać się na różne sposoby. O modelu wyspowym Wrighta już wspominaliśmy. W szczególnej sytuacji, gdy osiedla ludzkie położone są na przykład wzdłuż rzeki czy w kotlinie górskiej, geny napływają do badanej miejscowości z dwu stron, $\mathrm{z}$ osiedli położonych wzdłuż jednej linii. Opisują to modele jednowymiarowe nieciągłe (,schodkowe"), gdy geny przepływają skokowo z miejscowości 3 do 2, z 2 do 1 i z 1 do badanej (B) oraz ciągłe, gdy napływ genów odbywa się także bezpośrednio z dalej położonych osiedli (ryc. 1).

$\mathrm{O}$ wiele częściej wymiana partnerów a wraz z nimi genów, które wnoszą do puli genowej, odbywa się w przestrzeni dwuwymiarowej. Modele dwuwymiarowe (podobnie jak poprzednio - nieciągłe, „schodkowe” oraz bliższe rzeczywistości - ciągłe) opisują napływ genów do badanej miejscowości z czterech stron (ryc. 2) (Cavalli-Sforza i Bodmer 1971; Henneberg 1979; Malinowski i Strzałko 1985).

Prawdopodobieństwa kojarzenia się małżonków pochodzących $\mathrm{z}$ różnych odległości $\mathrm{w}$ pary ujmowano $\mathrm{w}$ postaci szeregu matematycznych zależności funkcyjnych a tworzone na ich podstawie teoretyczne rozkłady tych prawdopodobieństw próbowano dopasowywać do rzeczywistych za pomocą rozmaitych, empirycznie znajdowanych współczynników (np. Cavalli-Sforza i Bodmer 1971; Erikson i in. 1973; Jorde 1980; Morton 1982; Sujoldžić 1988; Sujoldžić i in. 1989; Smith i Sherren 1989; Rudan i in. 1998). Okazywało się to niezwykle trudne zarówno ze względu na stopień komplikacji proponowanych metod, jak i brak jednoznaczności w ocenie płynących z nich wyników. Pamiętajmy też, że zmienną, którą w tych modelach oceniano najczęściej były geograficzne odległości pomiędzy miejscami urodzenia współmałżonków, tymczasem pewien

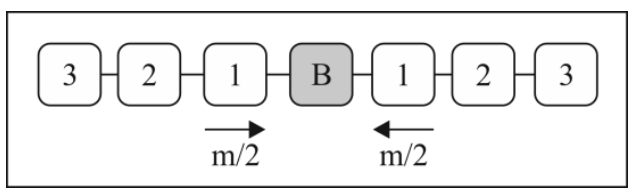

Ryc. 1. Jednowymiarowy model wymiany genów. B oznacza badaną miejscowość, numery 1, 2, 3 - miejscowości położone po jej obu stronach wzdłuż jednej linii, m - natężenie migracji. Strzałki skazują kierunek przepływu genów. Dalsze objaśnienia w tekście. Źródło: opracowanie własne na podstawie Cavalli-Sforza i Bodimer 1971; Henneberg 1979; Malinowski i Strzałko 1985 
stopień izolacji w kontaktach międzyludzkich może wynikać z innych przyczyn, niż bariery czy odległości geograficzne - mogą mieć one charakter różnych zmiennych kulturowych. Henneberg (1976) zwraca tu uwagę, między innymi, na nakłady energetyczne, jakie trzeba ponieść na pokonanie odległości między osadami, by mieć szansę na poznanie potencjalnego życiowego partnera. Dla określenia i analizy takich specyficznych kontaktów Boyce wprowadził koncepcję tzw. „znajomości sąsiedzkiej” (neighbourhood knowledge). Chodzi tu także o ponoszone koszty ekonomiczne wynikające z sieci dróg, dostępności środków transportu itp. Nie mniej ważne są ludzkie wierzenia i bariery wyznaniowe a także preferowany na danym terenie i w danej grupie ludzkiej system kojarzeń małżeńskich (Henneberg 1976). System kojarzeń małżeńskich jest przejawem działalności kulturowej o decydującym znaczeniu dla wewnątrzi międzygrupowej wymiany genów. Jego analiza pozwala wnioskować o stanie i zachodzących $w$ czasie przemianach pul genowych populacji. Jednymi z elementów systemu kojarzeń małżeńskich są endo- i egzogamia. Współczynniki endo- i egzogamii dostarczają informacji o przestrzennej strukturze zawierania małżeństw. Przypomnijmy, że pojęcie endogamii oznacza, najogólniej rzecz ujmując, kojarzenie się w obrębie tej samej grupy, egzogamii - zawieranie małżeństw pomiędzy członkami różnych grup. Współczynniki endo- i egzogamii pozwalają na ocenę stopnia izolacji genetycznej grup ludzkich a jako elementy składowe współczynników wsobności i spokrewnienia wewnątrzgrupowego stanowią zarówno źródło informacji kulturowej, jak i genetycznej (Budnik 2005a).

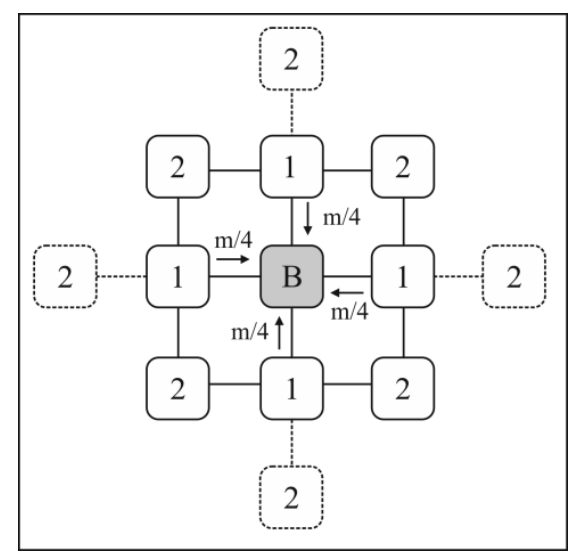

Ryc. 2. Dwuwymiarowy model wymiany genów. B - badana miejscowość, 1,2-miejscowości, z których napływają geny, m - natężenie migracji. Strzałki wskazują kierunek przepływu genów. Dalsze objaśnienia w tekście. Źródło: opracowanie własne na podstawie Cavalli-Sforza i Bodimer 1971; Henneberg 1979; Malinowski i Strzałko 1985 
Dobre modele określające sposób wymiany genów wynikający z systemu kojarzeń małżeńskich zaproponował M. Henneberg (1976, 1977, 1979). Określają one prawdopodobieństwo zawarcia związku małżeńskiego pomiędzy osobą $\mathrm{z}$ danego osiedla $\mathrm{z}$ partnerem $\mathrm{z}$ innego osiedla, łączą $\mathrm{w}$ sobie przy tym informacje zarówno o odległościach geograficznych, jak i kulturowych. Prawdopodobieństwo to zależy od natężenia egzogamii $(\mathrm{m})$, sposobu rozmieszczenia osiedli w przestrzeni $\left(N_{c}\right)$ oraz od tzw. rzędu sąsiedztwa $(O N)$. Rząd sąsiedztwa jest miarą sposobności do kontaktów między mieszkańcami różnych osiedli. W najprostszej sytuacji, przy braku barier izolacyjnych, jedynymi czynnikami określającymi wielkość rzędu sąsiedztwa $O N$ będą odległość geograficzna i rozmieszczenie osiedli. Dla grup ludności zamieszkujących miejscowości położone bezpośrednio obok siebie, rząd sąsiedztwa równy będzie jedności, gdy rozdziela je jedna miejscowość, $O N=2$ itd. Rozkład prawdopodobieństw zawierania małżeństw przez osoby pochodzące z różnych odległości $O N$ odbija wtedy rozkład odległości geograficznych. Pojawienie się jakichkolwiek barier geograficznych lub kulturowych zaburza ten obraz - mogą pojawić się utrudnienia w kontaktach nawet między osobami z miejscowości położonych bardzo blisko siebie. W takiej sytuacji odległość między nimi można określić jako rząd sąsiedztwa dalszy, niżby to wynikało $\mathrm{z}$ prostej odległości geograficznej. Możliwa jest oczywiście także sytuacja odwrotna. Rząd sąsiedztwa jest czymś więcej, niż odległość geograficzna - jest odległością ekologiczno-kulturową.

Podstawowa, wyjściowa wersja modelu Henneberga (1979) ma postać następującą:

$$
P_{O N}=\left(\sum_{O N=1}^{\alpha} \exp -\frac{O N^{2}}{N_{c} m}\right)^{-1} \exp -\frac{O N^{2}}{N_{c} m}
$$

Wyrażenie $P_{O N}$ w tym równaniu oznacza prawdopodobieństwo zawarcia małżeństwa z partnerem z odległości $O N$, $O N$ to rząd sąsiedztwa, $N_{c}$ oznacza liczbę osiedli w odległości $O N, m$ jest współczynnikiem egzogamii, natomiast $\alpha$ to rząd sąsiedztwa, w którym sumowane wyrażenie równa się praktycznie zeru.

Ten wyjściowy model można modyfikować przystosowując go do różnych sytuacji badawczych. Gdy migracja odbywa się równomiernie we wszystkich kierunkach na płaszczyźnie, gdzie osiedla ludzkie rozmieszczone są mniej więcej w równej odległości, mówimy o izotropii dwuwymiarowej (2DIM). Powyższe równanie przybierze wówczas poniższą postać (Henneberg 1979):

$$
P_{O N}=\left(\sum_{O N=1}^{\alpha} \exp -\frac{O N}{2 \pi m}\right)^{-1} \exp -\frac{O N}{2 \pi m}
$$


Jest to sytuacja, która występuje najczęściej. Może się jednak zdarzyć, że $\mathrm{z}$ jednej strony pojawi się znaczna bariera izolująca, która sprawi, że partnerzy będą napływać do badanej miejscowości z obszaru pomiędzy ramionami kąta $180^{\circ}-\mathrm{z}$,półpłaszczyzny”. Mówimy o izotropii 1,5-wymiarowej (1,5 DIM). Taka sytuacja wystąpiła, przykładowo, w miejscowościach Półwyspu Helskiego, gdzie od północy barierę stanowiło Morze Bałtyckie. Prawdopodobieństwo zawarcia małżeństwa przez osoby pochodzące z danej odległości $O N$ obliczyć można wtedy ze wzoru (Henneberg 1979):

$$
P_{O N}=\left(\sum_{O N=1}^{\alpha} \exp -\frac{O N}{\pi m}\right)^{-1} \exp -\frac{O N}{\pi m}
$$

Wreszcie, w przypadku izotropii jednowymiarowej (1 DIM), gdy osiedla położone są w jednej linii, na przykład wzdłuż kotliny górskiej, koryta rzeki itp., równanie to uzyska jeszcze bardziej uproszczoną formę (Henneberg 1979):

$$
P_{O N}=\left(\sum_{O N=1}^{\alpha} \exp -\frac{O N^{2}}{2 m}\right)^{-1} \exp -\frac{O N^{2}}{2 m}
$$

Zauważmy, że w każdej z trzech omówionych powyżej sytuacji równania mają tylko jeden parametr - wartość współczynnika egzogamii $m$.

Zalety modeli zaproponowanych przez Henneberga pokażemy na przykładzie historycznych populacji kaszubskich z Jastarni i Kuźnicy na Półwyspie Hel. Niezbędne informacje o małżeństwach, w tym o miejscach urodzenia współmałżonków, pozyskano z urzędowych, prowadzonych w gotyku niemieckim, ksiąg małżeństw za lata 1875-1919, zdeponowanych w Urzędzie Stanu Cywilnego w Jastarni oraz w Państwowym Archiwum w Gdańsku. Badaniami objęto 401 małżeństw. Były to wszystkie małżeństwa zawarte we wspomnianym wyżej okresie (Budnik 2005a, 2005b). Ze względu na specyfikę grup kaszubskich oraz położenie Półwyspu Helskiego bardzo trudno było dopasować rzeczywisty rozkład odległości małżeńskich do jakiejkolwiek sytuacji modelowej. Ponieważ od północy Bałtyk stanowił barierę izolacyjną dla osad półwyspu, zastosowano dla nich model kojarzenia pomiędzy ramionami kąta $180^{\circ}$. Gdy w równaniu Henneberga jednostki $O N$ potraktowano wyłącznie jako jednostki odległości geograficznych między miejscami urodzenia współmałżonków, teoretyczne i empiryczne rozkłady prawdopodobieństw zawarcia małżeństwa między osobami z tak potraktowanych odległości $O N$ różniły się zasadniczo $\left(\chi^{2}=58,04\right.$; p < 0,001; ryc. 3; Budnik 2005a).

Okazało się, że ani Półwysep Helski, ani inne tereny, z którymi Kaszubi wymieniali partnerów nie tylko nie wykazywały homogeniczności geograficznej, ale brakowało tam także homogeniczności kulturowej. Osiedla rozrzucone 


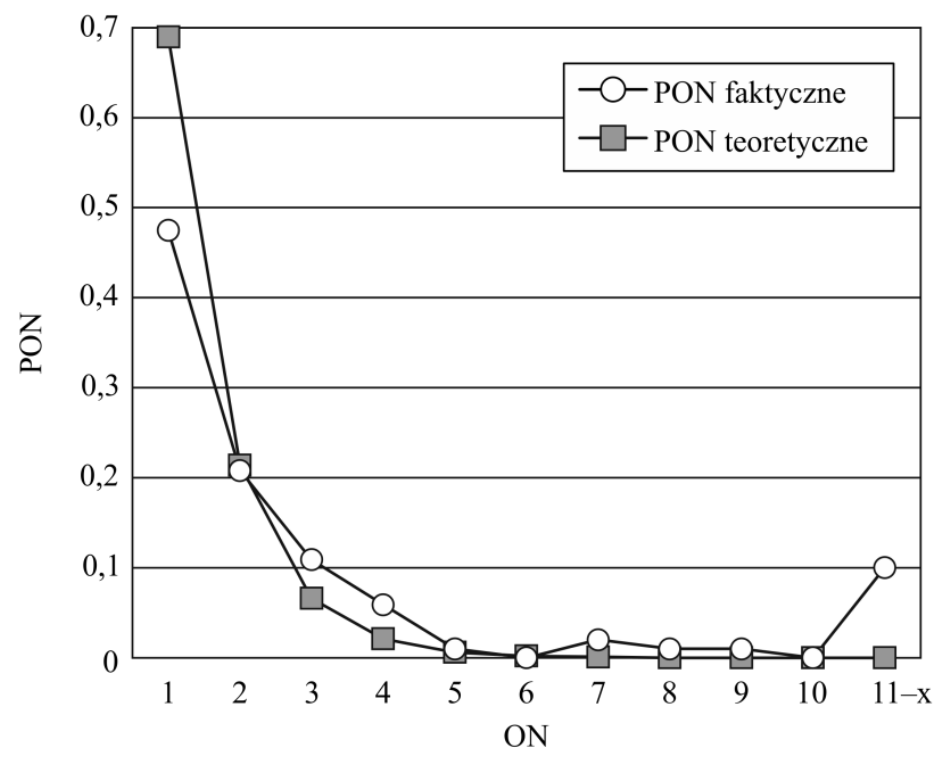

Ryc. 3. Rozkład odległości małżeńskich w populacjach kaszubskich z Jastarni i Kuźnicy w latach 1875-1919 dla izotropii 1,5-wymiarowej; odległości geograficzne $\left(\chi^{2}=58,04 ; p<0,001\right)$. Źródło: Budnik 2005a

były $\mathrm{w}$ terenie nierównomiernie, różniły się także wielkością, składem narodowościowym i etnicznym mieszkańców, używanym przez nich językiem, nazwiskami i wyznawaną religią a ponadto częstością kontaktów. Dochodziła do tego dwojaka rola wody w Zatoce Puckiej, która z jednej strony stanowiła czynnik izolujący, z drugiej jednak stawała się stosunkowo łatwą drogą transportu. Zwłaszcza latem przepływano Zatokę bardzo często w drodze do Gdańska, zimą te wyprawy były z oczywistych powodów rzadsze, ale i tak odbywały się przynajmniej co dwa tygodnie. Na początku XX wieku podróże te znacznie ułatwiła komunikacja parowcowa (Gołębiewski 1975; Budnik 2005a). Dopiero uwzględnienie wszystkich tych czynników i potraktowanie jednostek odległości $O N$ szerzej, jako odległości ekologiczno-kulturowych pozwoliło znaleźć model napływu genów do badanych miejscowości. Uzyskano doskonałą zgodność stworzonego w ten sposób rozkładu ekologiczno-kulturowych odległości małżeńskich z modelowym rozkładem dla izotropii 1,5-wymiarowej (ryc. 4; Budnik 2005a).

Typ rozkładu odległości pomiędzy miejscami urodzenia współmałżonków decyduje o sposobie przepływu genów w przestrzeni i o stanie puli genowej w badanych populacjach. W zależności od natężenia i przestrzennego rozkładu migracji małżeńskich różną formę będą przybierały wewnątrzgrupowe współczynniki spokrewnienia $f$. Współczynniki te można oceniać za pomocą 


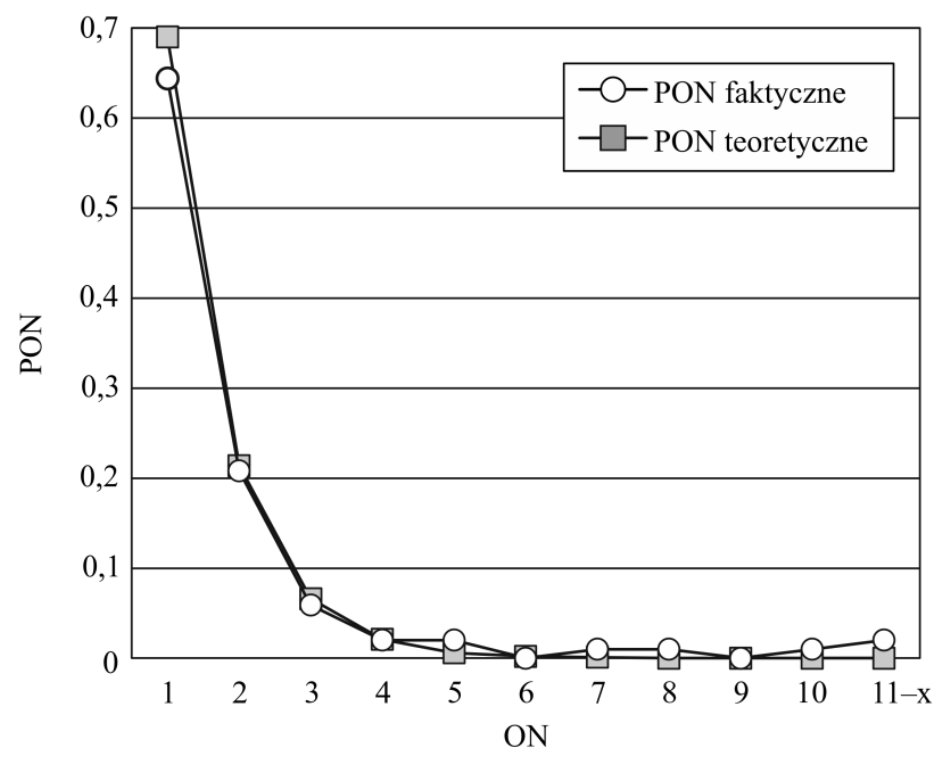

Ryc. 4. Rozkład odległości małżeńskich w populacjach kaszubskich z Jastarni i Kuźnicy w latach 1875-1919 dla izotropii 1,5-wymiarowej; odległości ekologiczno-kulturowe $\left(\chi^{2}=3,23\right)$. Źródło: Budnik 2005a

klasycznych równań Malécot'a (Cavalli-Sforza i Bodmer 1971) oraz wyprowadzonych z nich równań Henneberga (1978; 1979).

Według Malécot'a (Cavalli-Sforza i Bodmer 1971) mają one następującą postać:

(1) Dla migracji 2-wymiarowej

$$
f=\left[1+8 \pi \delta \sigma^{2}(-1 / \ln 2 b)\right]^{-1},
$$

gdzie $\delta$ to gęstość zaludnienia osobami zdolnymi do rozrodu, $2 \sigma^{2}-$ tzw. średni kwadrat odległości małżeńskich, zaś $b$ oznacza poprawkę na działanie liniowych nacisków stabilizujących pulę genów, co w praktyce sprowadza się do natężenia mutacji stwierdzanych u człowieka (przyjęto $b=5 \times 10^{-6}$ ).

(2) Dla migracji 1,5-wymiarowej - równanie Malécot'a trzeba było przekształcić do postaci przedstawionej poniżej (Budnik i Przybyszewska 1991)

$$
f=\left[1+2 \pi \delta \sigma^{2}(-1 / \ln 2 b)\right]^{-1}, \text { oznaczenia jak wyżej. }
$$

(3) Dla migracji 1-wymiarowej (Cavalli-Sforza i Bodmer 1971)

$$
f=[1+4 \delta \sigma \sqrt{2 b}]^{-1} .
$$


Według Henneberga (1979) odpowiednie formuły są następujące:

(1) Dla migracji 2-wymiarowej

$$
f=\left[1+32 \pi^{3} m^{3} N_{b}(-1 / \ln 2 b)\right]^{-1} .
$$

(2) Dla migracji 1,5-wymiarowej

$$
f=\left[1+8 \pi^{3} m^{3} N_{b}(-1 / \ln 2 b)\right]^{-1} .
$$

(3) Dla migracji 1-wymiarowej

$$
f=\left[1+4 m N_{b} \sqrt{2 b}\right]^{-1} .
$$

Wyrażenie $N_{b}$ w równaniach oznacza tzw. efektywną wielkość populacji, czyli - w uproszczeniu - liczbę osób zdolnych do kojarzeń i uczestniczenia w rozrodzie; $m$ to współczynnik egzogamii; pozostałe wyrażenia są takie same, jak w równaniach Malécot'a.

Dla omawianych już wcześniej populacji kaszubskich z Półwyspu Helskiego obliczono wartości współczynników wewnątrzgrupowego spokrewnienia $f$ dla migracji 1,5-wymiarowej, pomiędzy ramionami kąta $180^{\circ}$. Wartości $f$ oszacowane metodą Malécot'a przedstawia tabela 1 (Budnik 2005a).

Tabela 1. Współczynniki spokrewnienia wewnątrzgrupowego $f$ oszacowane metodą Malécot’a dla historycznych populacji kaszubskich z ,przeciętnej” osady Półwyspu Helskiego

\begin{tabular}{|l|c|c|}
\hline \multicolumn{1}{|c|}{ Okres } & $2 \sigma^{2}$ & $f$ \\
\hline \multirow{2}{*}{$1875-1899$} & $452330^{\mathrm{a}}$ & 0,0000005 \\
& $69^{\mathrm{b}}$ & 0,003 \\
\hline \multirow{2}{*}{$1900-1919$} & $2714634^{\mathrm{a}}$ & 0,00000009 \\
& $684^{\mathrm{b}}$ & 0,0004 \\
\hline Współcześnie & 29000 & 0,000005 \\
\hline
\end{tabular}

${ }^{a}$ Wszystkie pary

${ }^{\mathrm{b}}$ Bez kilku par z bardzo dużych odległości (głównie z USA)

Źródło: Budnik 2005a

Jak widać, szacunki współczynnika $f$, zwłaszcza dla populacji historycznych, są tu nieprawdopodobnie niskie, znacznie niższe niż dla grup współczesnych. Jedną ze składowych równania Malécot'a jest wariancja odległości pomiędzy miejscami urodzenia małżonków, określana jako średni kwadrat odległości. Obecność nawet niewielkiej liczby par pochodzących z dużych odległości natychmiast bardzo mocno podnosi tę wariancję, czego konsekwencją jest 
wydatne obniżenie wartości $f$. Właśnie taka sytuacja miała miejsce wśród Kaszubów helskich. Spadek wartości współczynnika spokrewnienia wewnątrzgrupowego spowodowało tam zaledwie kilka par, w których jedno ze współmałżonków urodziło się w USA. Ów spadek pozornie tylko świadczy o zmniejszeniu się spokrewnienia wewnątrzgrupowego, w rzeczywistości bowiem pary te miały kaszubskie pochodzenie, na kontynencie amerykańskim kojarzyły się we własnym, hermetycznym kręgu i w końcu na Półwysep Helski wróciły (Budnik 2005a). Usunięcie tych par $\mathrm{z}$ materiału spowodowało gwałtowne zmniejszenie się wariancji odległości małżeńskich i kilkutysięczny (!) wzrost wartości $f$ (tabela1).

Współczynniki $f$ oszacowane metodą Henneberga wolne są od tych niedogodności i dały o wiele wyższe wartości (tabela 2). Bardzo niskie wartości współczynników egzogamii $m$, które wchodzą w zakres tych formuł, także wskazują na kojarzenie się w bardzo wąskim kręgu. Popierają one wartości $f$ Henneberga a kłócą się z wartościami $f$ uzyskanymi z równania Malécot’a.

Tabela 2. Współczynniki spokrewnienia wewnątrzgrupowego $f$ oszacowane metodą Henneberga dla historycznych populacji kaszubskich z ,przeciętnej” osady Półwyspu Helskiego

\begin{tabular}{|l|l|l|l|}
\hline \multicolumn{1}{|c|}{ Okres } & $N_{b}$ & $m$ & $f$ \\
\hline $1875-1899$ & 191 & 0,24 & 0,017 \\
\hline $1900-1919$ & 217 & 0,313 & 0,007 \\
\hline Współcześnie & 830 & 0,621 & 0,0005 \\
\hline
\end{tabular}

Źródło: Budnik 2005a

Równania Henneberga mają inną trudność - jest nią konieczność oszacowania efektywnej wielkości populacji $\left(N_{b}\right)$. Oszacowania $N_{b}$ są zawsze trudne. Opierają się one na założeniach idealizacyjnych praktycznie niemożliwych do spełnienia u człowieka, jak niezachodzenie na siebie kolejnych pokoleń, niezmienność liczby osób tworzących te pokolenia, czy wydawanie na świat przez każdą osobę z populacji tej samej liczby potomstwa (Cavalli-Sforza i Bodmer 1971; Henneberg 1978; Jorde 1980). Jest wiele sposobów szacowania efektywnej wielkości populacji (przegląd np. w pracy A. Budnik 2005a). Tu odtworzono ją jako $1 / 3$ średniej harmonicznej liczb ludności.

Ryciny 5 i 6 pokazują inne przykłady populacji, dla których obliczono wartości współczynnika egzogamii i współczynnika spokrewnienia wewnątrzgrupowego metodą Henneberga. Tym razem spełnione były wymogi dla izotropii dwuwymiarowej i takich równań użyto. Jak widać, ludność XIX -wiecznej rzymsko-katolickiej parafii Dziekanowice z mikroregionu Ostrowa Lednickiego już przed wprowadzeniem reformy uwłaszczenia chłopów charakteryzowała się najwyższą wartością współczynnika egzogamii i najniższą 
- współczynnika spokrewnienia wewnątrzgrupowego. Była to nowoczesna, otwarta populacja o ciekawej, sięgającej czasów średniowiecza historii, w której izolacja złamana została bardzo dawno temu (Budnik i in. 2004). Inna wielkopolska parafia, Szczepanowo (Henneberg 1977), miała współczynniki egzogamii niemal dwukrotnie niższe a współczynniki $f$ wyższe niż Dziekanowice. Najmniej korzystnie przedstawiała się uboga galicyjska parafia Wielkie Drogi z zaboru austriackiego (Puch 1993), gdzie egzogamia była ponad dwukrotnie niższa a spokrewnienie wewnątrzgrupowe ponad sześciokrotnie wyższe niż w parafii Dziekanowice. Po reformie uwłaszczeniowej wszystkie wartości $m$ wydatnie

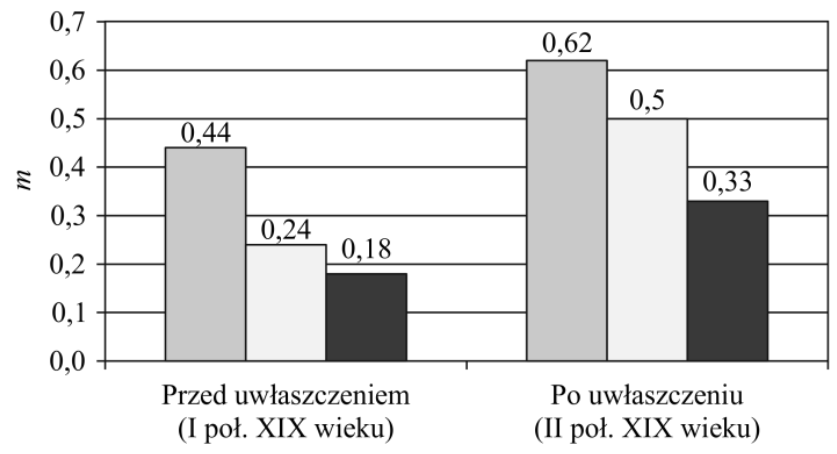

$\square$ Dziekanowice (1) $\square$ Szczepanowo (2) $\square$ Wielkie Drogi (3)

Ryc. 5. Wartości współczynnika egzogamii $m$ w wybranych parafiach wiejskich z XIX wieku.

Źródło: Budnik i in. 2004 (1); Henneberg 1977 (2); Puch 1993 (3)

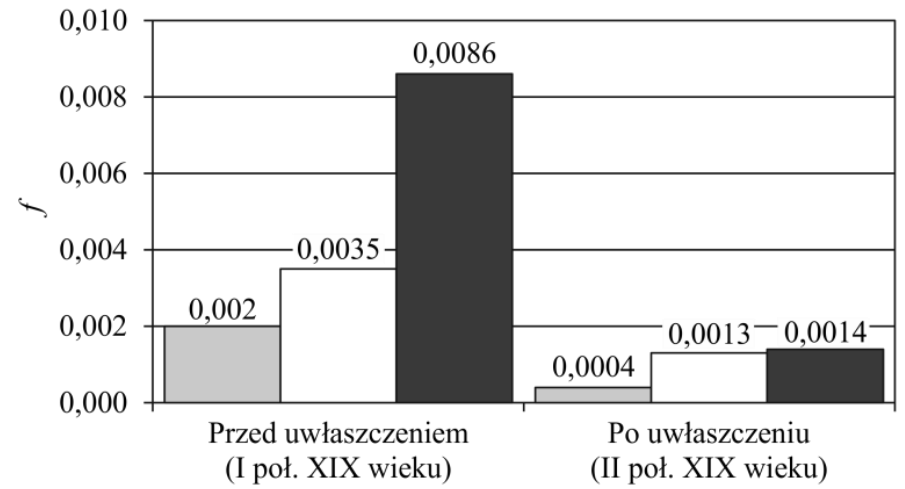

$\square$ Dziekanowice (1) $\square$ Szczepanowo (2) $\square$ Wielkie Drogi (3)

Ryc. 6. Wartości współczynnika spokrewnienia wewnątrzgrupowego $f$ w wybranych parafiach wiejskich z XIX wieku. Źródło: Budnik i in. 2004 (1); Henneberg 1977 (2); Puch 1993 (3) 
wzrosły a $f$ zmalały, choć różnice między parafiami utrzymywały się nadal (ryc. 5 i 6). Widać więc, jak ważne wydarzenia o charakterze gospodarczym i społecznym odbijały się w omawianych miernikach.

Wszystkie powyższe przykłady pokazują, że strukturę genetyczną populacji z powodzeniem odtwarzać można na podstawie macierzy migracji małżeńskich i odległości między miejscami urodzeń współmałżonków. Można do tego celu wykorzystać również częstości nazwisk wśród małżonków, uwzględniając częstość par izonimicznych, czyli takich gdzie małżonkowie już przed ślubem nosili to samo nazwisko.

Idea użycia danych o małżeństwach pomiędzy osobami nazywającymi się przed ślubem tak samo, jako źródła informacji genetycznej nie jest nowa i sięga 1875 roku, kiedy to G. H. Darwin, syn słynnego Karola Darwina, opublikował w Dziennikach Towarzystwa Statystycznego artykuł o konsekwencjach zawierania małżeństw pomiędzy kuzynami I stopnia w Anglii. Jednak dopiero 90 lat później Crow i Mange (1965), a po nich i inni, sformułowali zasady szacowania współczynników wsobności w oparciu o analizę izonimii. W literaturze przedmiotu często podkreśla się, że w naszym kręgu cywilizacyjnym, gdzie dziedziczenie nazwisk jest patrylinearne, nazwiska zachowują się jak geny sprzężone $\mathrm{z}$ chromosomem Y (np. Jobling 2001; Graf i in. 2010; Boattini i in. 2011). Metoda izonomii doczekała się też uwag krytycznych (np. Rogers 1991; Mielke i Swedlund 1993). Mimo to nadal stanowi ona jeden z najwygodniejszych sposobów estymacji inbredu.

Crow i Mange (1965) wyróżnili dwa komponenty składające się na wartość współczynnika wsobności $F$ szacowanego z nazwisk - część wynikającą z losowego kojarzenia się małżeństw $\left(F_{r}\right)$ oraz część wynikającą z kojarzenia nielosowego $\left(F_{n}\right)$. Klasyczne równania przedstawiają się następująco:

$$
\begin{gathered}
F=F_{n}+\left(1-F_{n}\right) F_{r}, \\
\mathrm{~F}_{\mathrm{n}}=\left(\mathrm{P}-\Sigma p_{i} q_{i}\right) / 4\left(1-\Sigma p_{i} q_{i}\right), \\
F r=\Sigma p_{i} q_{i} / 4,
\end{gathered}
$$

gdzie: $F$ oznacza współczynnik wsobności całkowitej; $F_{n}$ - współczynnik wsobności wynikający z nielosowego kojarzenia się małżeństw; $F_{r}$ - współczynnik wsobności wynikający z losowego kojarzenia się małżeństw; $p_{i}$ - częstość danego nazwiska u żon; $q_{i}$ - częstość danego nazwiska u mężów oraz $P$ - częstość par izonimicznych.

W przypadku braku istotnych różnic w częstościach nazwisk żon i mężów wyrażenie $\Sigma p_{i} q_{i}$ można zastąpić przez $\Sigma x_{i}$ gdzie $x_{i}$ oznacza częstość danego nazwiska w obu grupach małżonków łącznie.

Najczęściej powtarzające się nazwiska w historycznych populacjach kaszubskich w Jastarni i Kuźnicy przedstawiono w tabeli 3. W Jastarni 6 nazwisk 
wyczerpuje ponad 50\% całkowitej zmienności, 15 nazwisk - 75\%. W Kuźnicy ponad połowę zmienności wyczerpują tylko dwa nazwiska a 3/4 zmienności - zaledwie 6 nazwisk.

Tabela 3. Najczęściej spotykane nazwiska w osadach kaszubskich z Półwyspu Helskiego w latach 1875-1919

Źródło: opracowanie własne

\begin{tabular}{|l|c|l|c|}
\hline \multicolumn{2}{|c|}{ Jastarnia } & \multicolumn{2}{c|}{ Kuźnica } \\
\hline Nazwisko & $\%$ & Nazwisko & $\%$ \\
\hline Konkel & 20 & Budzisz & 34,6 \\
\hline Kohnke & 9,7 & Konkel & 19,1 \\
\hline Muża & 7,3 & Muża & 8,4 \\
\hline Herrmann & 6,8 & Dettlaff & 7,5 \\
\hline Selin & 4,8 & Nimoth & 4,4 \\
\hline Barlasch & 3,5 & Struck & 4 \\
\hline
\end{tabular}

Tabela 4 zawiera wartości współczynników wsobności $F$ i frakcje małżeństw izonimicznych $P$ w populacjach z Jastarni i Kuźnicy oraz innych wybranych populacji polskich.

Tabela 4. Wartości współczynników wsobności $\mathrm{F}$ i frakcje małżeństw izonimicznych $\mathrm{P}$ w wybranych populacjach polskich

\begin{tabular}{|l|c|c|c|c|}
\hline \multirow{2}{*}{ Populacja } & \multicolumn{2}{c|}{ XIX i początki XX wieku } & \multicolumn{2}{c|}{ Współcześnie } \\
\cline { 2 - 5 } & $F$ & $P$ & $F$ & $P$ \\
\hline Jastarnia & 0,016 & 0,064 & 0,009 & 0,035 \\
\hline Kuźnica & 0,044 & 0,17 & 0,04 & 0,156 \\
\hline Kartuskie & 0,003 & 0,012 & 0,005 & 0,019 \\
\hline Tatarzy & - & - & 0,017 & 0,063 \\
\hline Wielkopolska & 0,001 & 0,004 & 0,0005 & 0,002 \\
\hline
\end{tabular}

Źródło: opracowanie własne

Jak widać, w populacjach kaszubskich z Półwyspu Helskiego a także we współczesnych grupach Tatarów polskich wartości współczynnika $f$ są podwyższone w porównaniu z innymi populacjami. Szczególnie duże wartości inbredu oraz częstości par izonimicznych wystąpiły w Kuźnicy i ta sytuacja nie zmieniła się do dziś. Populacja kuźnicka prezentuje ponadto podwyższony poziom współczynnika $F_{n}$. Wynika on najprawdopodobniej z wybiórczego, pozytywnego kojarzenia się par małżeńskich ze względu na rozpoznawalny społecznie stopień pokrewieństwa, jaki odzwierciedla tu wspólne nazwisko (ryc. 7 i 8). 


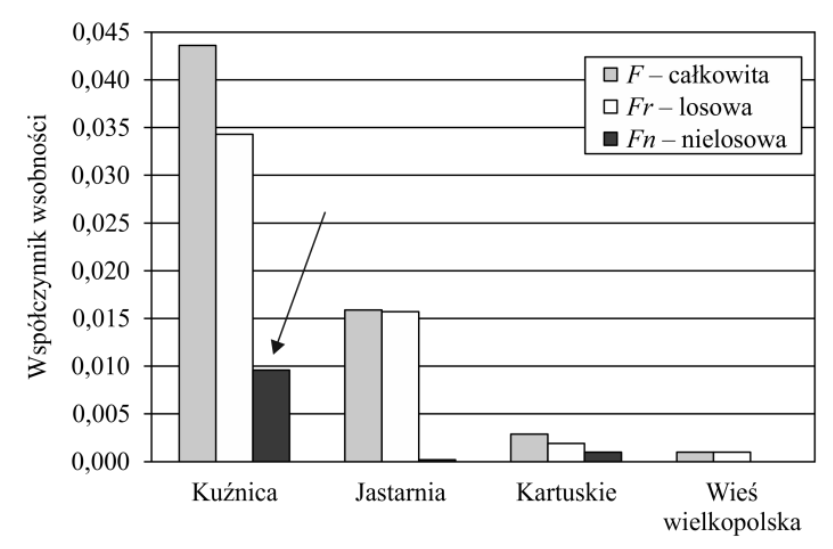

Ryc. 7. Wartości współczynników wsobności $F$ oszacowane metodą izonimii małżeńskiej w historycznych populacjach kaszubskich i w Wielkopolsce. Źródło: opracowanie własne

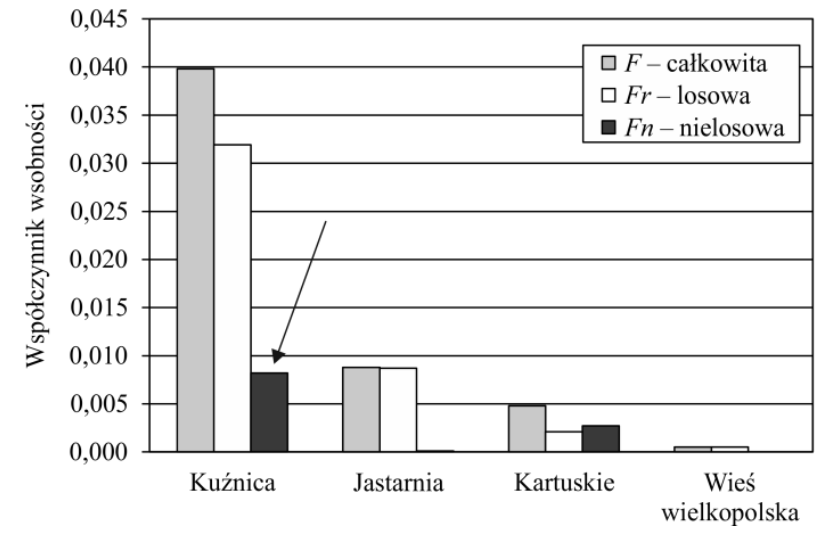

Ryc. 8. Wartości współczynników wsobności $F$ oszacowane metodą izonimii małżeńskiej we współczesnych populacjach kaszubskich i w Wielkopolsce.

Źródło: opracowanie własne

\section{BIBLIOGRAFIA}

Malinowski A., Strzałko J. (red.) 1985. Antropologia. Warszawa-Poznań: Państwowe Wydawnictwo Naukowe.

Boattini A., Luiselli D., Sazzini M., Useli A., Tagarelli G., Petlener D. 2011. Linking Italy and the Balkans. A Y-chromosome perspective from the Arbereshe of Calabria. Annals of Human Biology, 38(1): 59-68. 
Budnik A. 2000. Genetic structure of historical and contemporary Kashubian Populations in Poland. [in:] Susanne C.H., Bodzsár E.B. (red.) Human Population Genetics in Europe. Budapest: Eőtvős University Press, pp. 39-58.

Budnik A. 2005a. Uwarunkowania stanu i dynamiki biologicznej populacji kaszubskich w Polsce. Studium antropologiczne. Poznań: Wydawnictwo Naukowe UAM.

Budnik A. 2005b. System kojarzeń matżeńskich $w$ historycznych $i$ współczesnych populacjach kaszubskich z Jastarni $i$ Kuźnicy. Ocena stopnia izolacji genetycznej. Słupskie Prace Biologiczne, 1: 61-69.

Budnik A., Przybyszewska M. 1991. Genetic description of the population of Wielkie Drogi village - a specific case of mating distances distribution. Variability and Evolution, 1: 95 -103 .

Budnik A., Liczbińska G., Gumna I. 2004. Demographic Trends and Biological Status of Historic Populations from Central Poland: The Ostrów Lednicki Microregion. American Journal of Physical Anthropology, 125: 369-381.

Cavalli-Sforza L.L., Bodmer W.F. 1971. The Genetics of Human Populations. San Francisco: W.H. Freeman.

Crow J.F., Mange A.P. 1965. Measurement of inbreeding from the frequency of marriages between persons of the same surname. Eugenics Quarterly, 12: 199-203.

Darwin G. H., 1875, Marriages between first cousins in England and their effects. Journal of the Statistical Society of London, 38: 153-184.

Eriksson A.W., Fellman J. O, Workman P. L., Lalouel J. M. 1973. Population studies on the Aland Islands. I. Prediction of kinship from migration and isolation by distance. Human Heredity, 23: 422-433.

Gołębiewski H. 1975. Obrazki rybackie. Drugie wydanie na podstawie pierwodruku z 1888 roku. Gdańsk: Zrzeszenie Kaszubsko-Pomorskie, Oddział Miejski w Gdańsku.

Graf O.M., Zlojutro M., Rubicz R., Crawford M. 2010. Surname Distributions and Their Association with Y-Chromosome Markers in the Aleutian Islands. Human Biology, 82, 5-6: $745-757$.

Henneberg M. 1976. Izolacja grup ludzkich przez odległość. Model rozkładu odległości matżeńskich. [w:] Badania populacji ludzkich na materiałach wspótczesnych i historycznych. Poznań: Wydawnictwo Naukowe UAM, s. 117-125.

Henneberg M. 1977. Ocena dynamiki biologicznej wielkopolskiej dziewiętnastowiecznej populacji wiejskiej. II. System kojarzeń i plodność. Przegląd Antropologiczny, 43(2): 245-271.

Henneberg M. 1978. Ocena dynamiki biologicznej wielkopolskiej dziewiętnastowiecznej populacji wiejskiej. III. Opis stanu puli genów na podstawie danych demograficznych. Przegląd Antropologiczny, 44(1): 33-52.

Henneberg M. 1979. Breeding isolation between populations; theoretical model of mating distances distribution. Studies in Physical Anthropology, 5: 81-94.

Jobling M.A. 2001. In the name of the father: Surnames and genetics. Trends in Genetics, 17(6): 353-357.

Jorde L.B. 1980. The genetic structure of subdivided human populations. [in:] Mielke J.H, Crawford M.H. (eds.) Current Developments in Anthropological Genetics, vol. I, Theory and Methods, 1: 135-208.

Mielke J.H., Swedlund A.C. 1993. Historical demography and population structure. [in:] Lasker G.W., Mascie-Taylor C.G.N. (eds.) Research strategies in human biology: field and survey studies. Cambridge: Cambridge University Press, pp. 140.

Morton M.E. 1982. Estimation of Demographic Parameters from Isolation by Distance. Human Heredity, 32: 37-41. 
Puch E.A. 1993. Dynamika biologiczna polskich społeczności wiejskich z różnych systemów ekologiczno-kulturowych w XVIII i XIX wieku. Przegląd Antropologiczny, 56(1-2): 5-36.

Rogers A.R. 1991. Doubts about Isonymy. Human Biology, 63(5): 663-668.

Rudan I., Rudan P., Chaventre A., Janiájević B., Miličić J., Smolej-Narančić N., Sujoldžić A. 1998. Model-bound and model-free approach in the holistic analysis of population structure: Example from the island of Pag. Croatia. Homo - Journal of Comparative Human Biology, 49(2): 201-224.

Smith M. T., Sherren S. J. 1989. The one-dimensional stepping-stone model of migration: An application to British coastal populations. Collegium Anthropologicum, 13(1): 97-104.

Sujoldžić A. 1988. The Population Structure of the Island of Brač - A Demographic and Migrational Analysis. Collegium Anthropologicum, 12(2): 329-351.

Sujoldžić A., Jovanović V., Angel J. L., Bennett L. A., Roberts D. F., Rudan P. 1989. Migration within the island of Korcula, Yugoslavia. Annals of Human Biology, 16(6): 483-493. 